Calvo Salvador and Rodríguez-Hoyos International Journal of Educational Technology in Higher Education (2016) 13:13

DOI 10.1186/s41239-016-0005-2
- International Journal of Educational Technology in Higher Education

a SpringerOpen Journal

Open Access

\title{
Analizying MOOCs from an educational perspective in Spain
}

\author{
Adelina Calvo Salvador ${ }^{*}$ and Carlos Rodríguez-Hoyos
}

\footnotetext{
* Correspondence: calvoa@unican.es University of Cantabria, Cantabria, Spain
}

\begin{abstract}
This article is the result of a Teaching Innovation Project funded by the University of Cantabria's Vice-Rectorate for Teaching Staff. Its goals are to analyze the phenomenon of MOOCs with pedagogical criteria and to develop a Best Practice Guide. The project was developed by the Universities of Cantabria and Oviedo, all the work was divided into three phases: 1) Theoretical review and the design of classroom activities, 2) The implementation of classroom activities and analysis of the main results and 3) The development of a MOOC Best Practice Guide. The results of the second phase at the University of Cantabria are presented here. They demonstrate the need to introduce these massive open online courses into degree programmes in Education, updating higher education studies and providing valuable knowledge for understanding the educational potential (not just technological or financial) of this online training.
\end{abstract}

Keywords: MOOC, Higher education, Educational innovation, Best practice in MOOCs

\section{Springer}

\section{Introduction. Looking at MOOCs from an educational perspective}

Massive open online courses (MOOCs) have emerged in significant numbers in higher education since the first one appeared, rather randomly, in 2008 entitled "Connectivism and Connective Knowledge" carried out by George Siemens and Stephen Downes. Since then the number of participants, courses available and platforms for MOOCs have gradually increased.

The increase in the number of MOOCs cannot be understood without taking into account the postmodern dynamics of the globalization of knowledge, culture and communication together with the rise of lifelong training programmes (Gómez Galán, 2014). Despite the rapid expansion of this phenomenon and the many advantages highlighted by several authors (such as Gómez Galán, 2014, or Valverde, 2014), some critical voices have noted the need to take into consideration the fact that although the use of the network provides a semblance of freedom, in the end it is an instrument under the control of the social and political elites. Therefore, it is a good idea to view it from a distance and analyze it without being seduced by its apparent novelty or the breakaway or revolutionary model it appears to represent (Gómez Galán, 2014; Silva-Peña, 2014; Vázquez et al., 2013).

These types of training programmes are understood to be a continuation or evolution of e-learning (Roig et al., 2014) requiring more in-depth research into educational models supporting these courses with the objective of achieving a model based on sustainable 
quality. Some of the difficulties identified by the research, such as the high numbers of students or assessment methods based on quantitative parameters and a product model, need to be considered too (Alemán et al., 2015; Sánchez-Vera \& Prendes-Espinosa, 2015).

In addition to using technological criteria, the development of pedagogical criteria providing knowledge on which proposals maintain courses and how they can be improved is also necessary. Thus, some of the issues identified were:

- Lowering dropout levels among participants. How to fully engage all students on courses, particularly the least motivated ones (García et al., 2015) or manage the complexity and diversity of MOOC participants better (DeWaard et al., 2011), not only recognizing the most obvious sources of diversity such as culture, language or place of origin (Kop, 2011), but also by understanding their goals, expectations and perspectives (Yousef et al., 2015).

- Improving assessment methods in MOOCs. This involves promoting research in this field, taking into account the advantages and disadvantages presented by the assessment tools already being used (quizzes, peer assessment, etc.) and envisaging new methods such as group assessment or portfolios (O'Toole, 2013; Sánchez-Vera \& Prendes-Espinosa, 2015). Other studies propose the development of MOOC quality indicators, either from a comparative analysis of two methods for measuring the quality of courses (Baldomero et al., 2015), or by identifying a set of factors for its assessment, for example, pedagogical, functional, technological and time factors (Atenas, 2015).

- Reviewing educational content in MOOCs. The democratization of the contents is necessary, applying the philosophy of OER (Open Educational Resources) to these types of courses, once it has been verified that the main platforms offering open courses do not allow their reuse, revision, remixing or redistribution (Atenas, 2015).

- Generating proposals for best practice in MOOCs (Bali, 2014; Conole, 2014; Spyropoulou et al., 2014), above all in teacher training processes.

\section{Object of study and research methodology}

Our research project was organized around two main objectives: 1) Promoting awareness of MOOCs and analyzing it within the context of some educational degree programmes and 2) Using this preliminary analysis and developing it with the aim of establishing a MOOC Best Practice Guide.

The project was developed collaboratively between the Universities of Cantabria and Oviedo and took place over one year (July 2014-July 2015). The research team consisted of a range of 15 professionals. Although the project was developed in the two locations mentioned above and divided into three phases, in this paper we will focus on the results of the second phase at the University of Cantabria.

The pedagogical analysis of these courses, which dealt with subjects related to education, was linked to a classroom activity that was developed with varying degrees of depth in a number of subjects within different degrees courses at the Universities of Cantabria and Oviedo. The objective was to update these courses and improve university teaching. It was considered, on the one hand, that young people should know about and analyze MOOCs and, on the other hand, the process of accompanying, using a qualitative methodology during the implementation and assessment of the activity could help us to improve our 
teaching. The analysis carried out in the classroom and the process of forward planning and assessment was used to help us develop a MOOC Best Practice Guide, a task that was addressed in the final phase of the project.

\section{Project phases}

The project was developed in three phases, as summarized in Table 1 below.

\section{Methodological aspects of Phase 2: Analysis of MOOCs}

The group classroom activity was developed in this phase. It consisted in analyzing educational/pedagogical subjects in MOOCs that were being developed in Spanish based on an analysis template designed by the research team.

Three official degrees were involved in the project at the University of Cantabria. In the bachelor's degree in Teaching programmes (Pre-school and Primary Education), we carried out work on a subject called "Curriculum, Society and Teaching Teams" (second year). On the master's degree course called Research and Innovation in Educational Contexts, our research focused on two subjects ("Educational Technology and Digital Competence" and "New Forms of Communication, Learning and Assessment in the Knowledge Society"), both of which formed part of the same module called "Using ICT: Innovation and Research in Education". At the University of Oviedo, research was carried out within the bachelor's degree in Pedagogy programme on the subjects "Analysis of Methods and Materials for Education and Training" (third year) and "Virtual Environments for Education and Training" (fourth year).

The first part of the activity was dedicated to explaining this phenomenon, in which the emergence of MOOCs, what they consist of and the impact they are having worldwide was discussed. Subsequently, group work was developed where students analyzed the pedagogical aspects of MOOCs in Spanish. Students were provided with a list of 18 platforms so that they could enter them and choose those subjects they were interested in. Each MOOC was reviewed using an analysis template developed ad hoc and divided into the following sections:

1) General aspects. Course name, organization responsible, duration, etc.

2) Definition and type of MOOC. Student limitations, level of openness, etc.

Table 1 Project phases and objectives

\begin{tabular}{|c|c|}
\hline \multicolumn{2}{|c|}{ Title: "Best practice in MOOCs in the field of education. Analysis of courses and proposals for improvement" } \\
\hline Phase & Specific objectives \\
\hline 1. Training the work team and reviewing the literature & $\begin{array}{l}\text { - Reviewing the literature. } \\
\text { - Choosing platforms and types of course to analyze. } \\
\text { - Planning the classroom activity with varying degrees } \\
\text { of depth. } \\
\text { - Planning the process of monitoring the activity. }\end{array}$ \\
\hline 2. Analysis of MOOCs & $\begin{array}{l}\text { - Development of the classroom activity (4 subjects } \\
\text { from } 3^{\circ} \text { courses in Education at the University of } \\
\text { Cantabria and } 2 \text { subjects from } 1^{\circ} \text { course in Education } \\
\text { at the University of Oviedo). } \\
\text { - Documentation of the process. }\end{array}$ \\
\hline 3. Creation of a MOOC Best Practice Guide & $\begin{array}{l}\text { - Summary of work carried out in phase } 2 . \\
\text { - Creation of a Best Practice Guide. }\end{array}$ \\
\hline
\end{tabular}


3) Formal aspects. Design, accessibility level, etc.

4) Pedagogical aspects. Analysis of the objectives, interaction, guides, contents, etc.

5) Assessment of the course and other notable aspects. Open section where a more global discussion could be developed, taking into account the positive and negative aspects of the course.

During the development and assessment of the activity, the experience was documented using tools for gathering data based on a qualitative research methodology (Barbour, 2013; Flick, 2012; Kvale, 2013). The methods used were classroom observation and writing a field diary, focus groups and interviews. A manual process of coding and subject classification was used for the purpose of analyzing the data (Gibbs, 2012).

In each subject, one of the project researchers went to a classroom to carry out an observation session and then write a field diary. With the information gathered, a focus group was organized, in which the teacher who developed the activity, the external observer (who acted as a facilitator) and a group of students participated. Inspired by lesson studies (Cerbin \& Kopp, 2006), the objective was to discuss the development of the class and its improvement. An audio recording was made of the discussion, which was later transcribed. Finally, a semi-structured interview with each teacher was conducted, in which the decision-making process in relation to the activity, class management, the role of students, etc. were analyzed, as summarized in Table 2 below.

This methodological design enabled us to link an educational research process to teaching innovation (Morales, 2010), given that the ultimate goal of the inquiry process was to improve university teaching and the educational degree programmes involved in the project.

\section{Results}

\section{Summary of the analysis of MOOCs}

We summarize Moocs analyzed in Table 3 below.

\section{The meaning of the activity in the subjects and degree programmes}

The activity was assessed with great interest by the participants. This process was carried out appropriately within the context of the subject and its contents. Promoting these courses, considered to be of great importance for the specialization of young people, was valued positively. The results of the assessment also recognized that the activity facilitated the development of skills such as analysis and research and that it was useful to the work of teachers (learning strategies that can be applied to the classroom) and researchers. For the participants, it allowed them to learn where distance learning and future education is going and its possible impact on universities in the future.

Students also recognized that this activity helped them widen their perspective on the curriculum:

"If we analyze the fact that the subject is called Curriculum, Society and Teaching Teams, we talk continuously about this, about how to approach a curriculum, about how you should think about what the first objective is (...). When you're faced with a MOOC platform, you think about all those things that you talk about in class, because you really think about the objective, about what you're going to do, about how to approach it (...). I don't know, I think it's related to what we talk about in 
Table 2 Data collection. Phase 2. Cantabria

\begin{tabular}{|c|c|c|c|}
\hline Subjects & Degrees & $\begin{array}{l}\text { Data collection: } \\
\text { methods }\end{array}$ & Participants in FG \\
\hline $\begin{array}{l}\text { Curriculum, Society and } \\
\text { Teaching Teams }\end{array}$ & $\begin{array}{l}\text { Bachelor's degree } \\
\text { in Teaching } \\
\text { - Pre-school Education }\end{array}$ & & $\begin{array}{l}\text { - } 4 \text { students } \\
\text { (3 females + } 1 \text { male) } \\
\text { - Teacher } \\
\text { - Observer/FG facilitator }\end{array}$ \\
\hline $\begin{array}{l}\text { Curriculum, Society and } \\
\text { Teaching Teams }\end{array}$ & $\begin{array}{l}\text { Bachelor's degree } \\
\text { in Teaching } \\
\text { - Primary Education }\end{array}$ & & $\begin{array}{l}\text { - } 4 \text { students } \\
\text { (3 females +1 male) } \\
\text { - Teacher } \\
\text { - Observer/FG facilitator }\end{array}$ \\
\hline \multirow{2}{*}{$\begin{array}{l}\text { - Educational Technology and } \\
\text { Digital Competence } \\
\text { - New Forms of Communication, } \\
\text { Learning and Assessment in the } \\
\text { Knowledge Society }\end{array}$} & $\begin{array}{l}\text { Master's degree } \\
\text { in Research and } \\
\text { Innovation in } \\
\text { Educational Contexts }\end{array}$ & $\begin{array}{l}\text { - Classroom observations } \\
\text { - Field diaries } \\
\text { - Focus groups } \\
\text { - Interviews }\end{array}$ & $\begin{array}{l}\text {-2 students (females) } \\
\text { - Teacher } \\
\text { - Observer/FG facilitator }\end{array}$ \\
\hline & & & $\begin{array}{l}\text { TOTAL: } 16 \text { participants } \\
\text { (10 students }+3 \text { teachers + } \\
3 \text { observers/facilitators) }\end{array}$ \\
\hline
\end{tabular}

class, how to do it and what you want to achieve, the way you're doing it (...). It's connected because that's what it is, how you create a curriculum, what direction it's going in, what its objectives are" (FG 1).

It demonstrated the extent to which online courses exemplify diverse ways of educating. They understood that the activity had a place in any discipline in their curriculum

Table 3 The analysis of MOOCs

\begin{tabular}{|c|c|c|c|}
\hline Degrees & Subjects & Platforms & Courses \\
\hline $\begin{array}{l}\text { Bachelor's degree } \\
\text { in Teaching } \\
\text { - Pre-school Education }\end{array}$ & $\begin{array}{l}\text { Curriculum, Society } \\
\text { and Teaching Teams }\end{array}$ & $\begin{array}{l}\text { - UPV.ES } \\
\text { - MiriadaX } \\
\text { - EducaLAB } \\
\text { - AbiertaUGR.es } \\
\text { - ECO Learning } \\
\text { - Coursera }\end{array}$ & $\begin{array}{l}\text { - Educational technology } \\
\text { - Methodological strategies } \\
\text { for teaching e-learning } \\
\text { - PISA and TIMSS questions. } \\
\text { An activity for the classroom } \\
\text { - Creating a virtual course } \\
\text { on the Moodle platform } \\
\text { - Digital identities } \\
\text { - Creative skills for teachers } \\
\text { (Creativity MOOC Camp) } \\
\text { - Educational innovation and } \\
\text { professional development. } \\
\text { ICT opportunities and limits } \\
\text { - Social psychology }\end{array}$ \\
\hline $\begin{array}{l}\text { Bachelor's degree } \\
\text { in Teaching } \\
\text { - Primary Education }\end{array}$ & $\begin{array}{l}\text { Curriculum, Society } \\
\text { and Teaching Teams }\end{array}$ & $\begin{array}{l}\text { - MiriadaX } \\
\text { - Coursera }\end{array}$ & $\begin{array}{l}\text { - Applying social networks to } \\
\text { teaching. Virtual Communities } \\
\text { - Statistics for researchers. Everything } \\
\text { you wanted to know } \\
\text { - Be more creative } \\
\text { - Robots and videogames in } \\
\text { the classroom. Scratch and } \\
\text { Arduino for teachers } \\
\text { - Managing anxiety before exams } \\
\text { and oral presentations }\end{array}$ \\
\hline \multirow[t]{2}{*}{$\begin{array}{l}\text { Master's degree } \\
\text { in Research and } \\
\text { Innovation in } \\
\text { Educational Contexts }\end{array}$} & $\begin{array}{l}\text { - Educational Technology } \\
\text { and Digital Competence } \\
\text { - New forms of Communication, } \\
\text { Learning and Assessment in the } \\
\text { Knowledge Society }\end{array}$ & $\begin{array}{l}\text { - MiriadaX } \\
\text { - Coursera }\end{array}$ & $\begin{array}{l}\text { - Applying social networks to } \\
\text { teaching: virtual communities } \\
\text { - Information and communication } \\
\text { technology in education }\end{array}$ \\
\hline & & Total: 6 & Total: 14 \\
\hline
\end{tabular}


because MOOCs address diverse academic content as well as issues of general interest (not belonging to any particular specialist field of knowledge). It was considered that the work with these courses should be cross-disciplinary within the curriculum.

On the other hand, the teachers said that what mattered most to them was to bring students closer to the field of education from another point of view, beyond formal education (Interview Teacher 1), in addition to the opportunity it offered for reflecting on innovation in subjects linked to virtual education, always from a didactic and communicative perspective (Interview Teacher 3):

“I tried to present something new, something that they didn't know and that by being new it seemed like it was going to be high quality, highly innovative and well, many groups were surprised by the fact that, when faced with the MOOCs they were analyzing, they found that teaching was more formal or even less advanced, or had formats that were more open or modern than they'd expected (...) not all courses are suitable for studying online either, as these are courses using the old online or e-learning methods" (FG 1).

Furthermore, they recognized the opportunities that creating an inter-university working group presented for developing a project that ultimately acted as a trigger for starting a reflection process on how to improve university teaching. Subsequently a small-scale research process was developed with this objective (Interview Teacher 2 and Teacher 3). The benefits of the group of teachers having diverse professional and research backgrounds were emphasised. For one of the teachers, this was an unmistakeable sign that work can be carried out at university beyond the competitive parameters that have been established, which are only focused on increasing scientific productivity, with teaching, management activities and outreach services being relegated to second place (Interview Teacher 2).

\section{Work methodology in the classroom}

Students and teachers demonstrated the potential of the teamwork methodology used for the development of the activity, emphasizing the added value of the high degree of autonomy observed among students (Interview Teacher 1). These, in turn, highlighted the opportunity the project gave them to share experiences and be autonomous (FG 1), investigate, experiment, carry out inductive work and organize class space as a place for exchange and dialogue that requires responsibility, commitment and involvement. They considered that teamwork is not just a type of work methodology in the classroom, but also a key skill within the context of the curriculum, given that it is essential in the training of education professionals, as demonstrated by its demand in the labour market (FG 3).

The teacher's role was viewed as a guidance counsellor (FG 2 and 3), someone who "does not give advice" but rather someone who was able to create a comfortable work environment where students felt free to ask questions (FG 3). The support given by teachers was rated as "adequate", the existence of two teachers in the classroom during the development of the activity was positively valued. This was the case on the master's degree course, where the observer had an active role in the development of the activity, providing support and guidance to the work groups, along with the teacher. 
The template items were assessed positively, it was understood that they were sufficiently broad, understandable and served as an excellent preliminary guide (FG 3). They were very useful for students and were valued as a complete tool which helped students gain an in-depth understanding of what a MOOC is and focus attention on issues that otherwise would have gone unnoticed in the context of the activity:

"[The analysis template] helps guide you in the course, but there are also aspects that you start thinking about later on (...). For example, the item on whether the information provided was accessible to all kinds of people, those with disabilities or not, caught my attention (...). I think that item is very good, but it's also true, at least from what I saw, that not all [courses] pay attention to all the capabilities that everyone might have" (FG 1).

Teachers noted the strengths of the methodology as performing an activity with varying degrees of difficulty and depth, collaborative design using diverse support material, the link between teaching and research in a university setting (Interview Teacher 2), the presence of two teachers in the classroom (Interview Teacher 3) and the application of learning that was being developed.

\section{Perceived barriers and improvements}

Regarding perceived barriers for the development of the activity and possible improvements, students and teachers indicated that one of the major difficulties in the development of the activity was the shortage of MOOCs in subjects related to education in Spanish, which could be analyzed while the activity was being developed (October, November and December 2014). Teachers also stressed the need for both the activity and the project as a whole to have more visibility in the curriculum and for the role of students to be more active, including being present during the design stage of the activity (Interview Teacher 3 ).

With regard to improvements, some students noted the need for carrying out a previous study on "browsing" or "superficial navigation" in several MOOC platforms before analysis (FG 1, 2 and 3), the possibility of analyzing proposals outside the field of education and encouraging all students on the degree course to participate in a MOOC suggesting that the activity be included as an option in more subjects in the degree programme (FG 1).

The teachers noted that it was essential for the results obtained to be visible, considering the relation of the work carried out to other educational subjects like attention to diversity, media education, etc., as well as recognizing the potential of the focus group following the activity as a tool for formative assessment (Interview Teacher 3). It was clear that this project could provide the impetus for another more ambitious one later on focusing on the improvement of university teaching, recognizing the potential of the focus groups mentioned above:

"I think it was a good start, because it has generated this idea to interview us, set up focus groups, talk among ourselves about how to do an activity together, but this is a gateway to something that I think should grow over time, in its complexity, length 
and thoroughness, that is, by being more demanding on ourselves, to improve university teaching" (Interview Teacher 2).

\section{Discussion of the results and prospects}

This project enabled us to carry out a pedagogical analysis of MOOCs within several university degree courses that address educational issues. As a result, we were able to present students with an educational reflection that goes beyond known classroom formats and open up a new field of study within online training. It sought to upgrade the educational curriculum and offer young people new resources for lifelong learning and future employment. This issue is becoming more urgent day by day if we take into account the emergence of MOOCs in Spanish universities, where the availability of such courses exceeds those offered in countries such as the United Kingdom, France or Germany. Taking into consideration participation in the global supply of MOOCs, Spain is among the five top countries in terms of the number of students following this educational approach, with only the United States, the United Kingdom, Canada and Brazil ahead of it (Oliver et al. 2014).

The participants valued the work carried out very highly, and suggested that the presence of MOOCs should be greater in the educational curriculum. The way we addressed our work was also positively assessed; the participants noted that classroom work enabled them to develop useful skills for their future work as teachers and researchers.

The educational analysis of MOOCs has not only been positive from the point of view of students and the subjects they are studying, but also this analysis, included in a wider project, has enabled the teachers involved to establish relationships between educational innovation and research, in such a way that the results obtained from the research can be transferred to the classroom. This facilitates the construction of rich pedagogical practices that provide the environments in which students develop skills increasingly in demand in the labour market while at the same time helping to create and build communities of practice (López et al., 2011), where higher education professionals can debate, discuss and share their thoughts on these processes with the overall objective of improving higher education.

The teachers involved believe that the project provided an opportunity to improve their teaching, sharing space with other teachers and their own students in order to carry out dialogue, reflect together and promote changes. This means that universities could exist within less competitive parameters, becoming more collaborative places and moving towards recovering the value of teaching in higher education, an activity that appears to have taken second place in the face of increasing demand for more productive or higher quality research, something that is assessed taking into account the means of dissemination (Dill, 2008).

This research has enabled us to confirm the need to expand the number of research projects focused on the pedagogical analysis of MOOCs, given that under the halo of novelty, transgression and rupture that such educational experiences present, it has been noted that many of the existing proposals are based on curricular concepts typical of the most traditional e-learning courses. Thus, this work follows the same lines as other contributions (Daniel et al., 2015; Silva-Peña, 2014; Valverde, 2014; Vázquez et al., 2013), which have suggested the need for further in- 
depth research into the pedagogical development of these proposals, which must, at least, develop at the same speed as the technological advances in the platforms that host these courses.

\author{
About the Authors \\ Adelina Calvo Salvador \\ calvoa@unican.es \\ Lecturer, Department of Education, University of Cantabria, Spain \\ With a doctorate in Pedagogy (University of Oviedo, Spain), Adelina Calvo Salvador is a lecturer in the Department of \\ Education at the University of Cantabria, Spain, in the area of Didactics and School Organization. She has worked on \\ research projects aimed at reducing the digital divide such as the European ECO Project: E-Learning, Communication \\ and Open Data (currently in progress), the Education Programme for Trainers in the Use of Digital Technology at Dueso \\ Prison, Cantabria, Spain, and the Digital Training Programme based on digital entertainment workshops for associations \\ and groups at risk of social exclusion. She is currently leading a project on best practice in MOOCs in the area of Education \\ and is taking part in analyzing courses and proposals for improvement funded by the University of Cantabria's \\ Vice-Rectorate for Teaching Staff. Some of her most important published papers include The Role of Tutors in \\ E-Learning, Contributions to Research Using Case Studies, RUSC. Universities and Knowledge Society Journal, 2011; \\ Weaving Networks: An Educational Project for Digital Inclusion, The Information Society, 2010; and Social Exclusion \\ and Technology, Comunicar, 2007. Her research interests include socio-educational inclusion/exclusion mediated \\ by technology, gender and education and school improvement. \\ Departamento de Educación \\ Universidad de Cantabria \\ Avda. de los Castros, s/n \\ 39005 SANTANDER \\ Spain \\ Carlos Rodríguez-Hoyos \\ rodriguezhc@unican.es \\ Lecturer, Department of Education, University of Cantabria, Spain \\ With a degree in Education Sciences and a doctorate in Pedagogy, Carlos Rodriguez-Hoyos currently works as a lecturer in \\ the Department of Education at the University of Cantabria, Spain, teaching on both undergraduate and postgraduate \\ courses. He has worked with UNED since 2006 on various official and non-official courses. He has carried out research in \\ several international universities including the University of Minho, Portugal, Loughborough University and Nottingham \\ University, England. He has also carried out research at the University of Santiago de Compostela, Spain. His research \\ interests include the study of the incorporation of Information and Communication Technologies into education, \\ e-learning and media education. He has published several significant articles in national journals such as Revista de \\ Educación, Revista de Educación XX1 and Revista de Curriculum and in international journals such as his article on \\ Behaviour, Information and Technology. He has also contributed to a number of books published in Spain, the USA \\ and Brazil. He is currently coordinating the research team at the University of Cantabria within the E-Learning, \\ Communication and Open Data Project. \\ Departamento de Educación \\ Universidad de Cantabria \\ Avda. de los Castros, s/n \\ 39005 SANTANDER \\ Spain
}

Received: 5 May 2015 Accepted: 1 July 2015

Published online: 02 March 2016

\title{
References
}

Alemán, L., Sancho-Vinuesa, T., \& Gómez, M. G. (2015). Indicadores de calidad pedagógica para el diseño de un curso en línea masivo y abierto de actualización docente. RUSC Universities and Knowledge Society Journal, 12(1), 104-119. http://dx.doi.org/10.7238/rusc.v12i1.2260

Atenas, J. (2015). Modelo de democratización de los contenidos albergados en los MOOC. RUSC Universities and Knowledge Society Journal, 12(1), 3-14. http://dx.doi.org/10.7238/rusc.v12i1.2031

Baldomero, M., Salmerón, J. L., \& López, E. (2015). Comparativa entre instrumentos de evaluación de calidad de cursos MOOC: ADECUR vs Normas UNE 66181:2012. RUSC Universities and Knowledge Society Journal, 12(1), 131-145. http:// dx.doi.org/10.7238/rusc.v12i1.2258

Bali, M. (2014). MOOC pedagogy: gleaning good practice from existing MOOCs. MERLOT Journal of Online Learning and Teaching, 10(1), 44-56. Retrieved from http://jolt.merlot.org/vol10no1/bali_0314.pdf

Barbour, R. (2013). Los grupos de discusión en la investigación cualitativa. Madrid, España: Morata.

Cerbin, W., \& Kopp, B. (2006). Lesson Study as a Model for Building Pedagogical Knowledge and Improving Teaching. International Journal of Teaching and Learning in Higher Education, 18(3), 250-257. Retrieved from http://www.isetl. org/ijtlhe/pdf/IJTLHE110.pdf

Conole, G. (2014). A new classification schema for MOOCs. INNOQUAL-International Journal for Innovation and Quality and in Learning, 2(3), 65-77.

Daniel, J., Vázquez Cano, E., \& Gisbert, M. (2015). The Future of MOOCs: Adaptive Learning or Business Model? RUSC Universities and Knowledge Society Journal, 12(1), 64-73. http://dx.doi.org/10.7238/rusc.v12i1.2475

DeWaard, I., Abajian, S., Gallagher, M. S., Hogue, R., Keskin, N., Koutropoulos, A., \& Rodriguez, O. C. (2011). Using mLearning and MOOCs to Understand Chaos, Emergence, and Complexity in Education. The International Review of 
Research in Open and Distance Learning, (12)7. Retrieved from http://www.irrodl.org/index.php/irrodl/article/view/ $1046 / 2026$

Dill, D. (2008). La degradación de la ética académica. In R. Barnett (Ed.), Para una transformación de la universidad. Nuevas relaciones entre investigación, saber y docencia (pp. 231-246). Barcelona, España: Octaedro.

Flick, U. (2012). Introducción a la investigación cualitativa. Madrid, España: Morata.

García, B. J., Tenorio, G. C., \& Ramírez, M. S. (2015). Retos de automotivación para el involucramiento de estudiantes en el movimiento educativo abierto con MOOC. RUSC Universities and Knowledge Society Journal, 12(1), 91-104. http:// dx.doi.org/10.7238/rusc.v12i1.2185

Gibbs, G. (2012). El análisis de datos cualitativos en investigación cualitativa. Madrid, España: Morata.

Gómez Galán, J. (2014). El fenómeno MOOC y la universidad de la cultura: las nuevas fronteras de la educación superior. Profesorado Revista de currículum y formación del profesorado, 18(1), 73-91.

Kop, R. (2011). The challenges to connectivist learning on open online networks: Learning experiences during a massive open online course. The International Review of Research in Open and Distance Learning, 12(3). Retrieved from http://www.irrodl.org/index.php/irrodl/article/view/882

Kvale, S. (2013). Las entrevistas en investigación cualitativa. Madrid, España: Morata.

López, J., Sánchez, M., \& Altopiedi, M. (2011). Comunidades profesionales de práctica que logran sostener procesos de mejora institucional en las escuelas. Revista de Educación, 356, 109-131.

Morales, P. (2010). Investigación e innovación educativa. REICE. Revista Iberoamericana sobre Calidad, Eficiencia y Cambio en Educación, 8(2), 43-73.

OToole, R. (2013). Pedagogical strategies and technologies for peer assessment in Massively Open Online Courses (MOOCs). Discussion Paper. UK: University of Warwick: University of Warwick, Coventry. (Unpublished). Retrieved from http:// wrap.warwick.ac.uk/54602/

Oliver, M., Hernández-Leo, D., Daza, V., Martín, C., \& Albó, L. (2014). MOOCs en España. Panorama actual de los Cursos Abiertos en Línea en las universidades españolas. Barcelona, España: Cátedra Telefónica-Universidad Pompeu Fabra. Retrieved from http://www.catedratelefonica.upf.edu/wp-content/uploads/2014/02/MOOCs-en-Espa\%C3\%B1a1.pdf

Roig, R., Mengual-Andrés, S., \& Suárez, C. (2014). Evaluación de la calidad pedagógica de los MOOC. Profesorado Revista de currículum y formación del profesorado, 18(1), 24-41.

Sánchez-Vera, M. M., \& Prendes-Espinosa, M. P. (2015). Más allá de las pruebas objetivas y la evaluación por pares: alternativas de evaluación en los MOOC. RUSC Universities and Knowledge Society Journal, 12(1), 119-131. http://dx. doi.org/10.7238/rusc.v12i1.2262

Silva-Peña, I. (2014). Utilización de MOOCs en la formación docente: ventajas, desventajas y peligros. Profesorado Revista de Currículum y Formación del Profesorado, 18(1), 155-166.

Spyropoulou, N., Pierrakeas, C., \& Kameas, A. (2014). Creating MOOC guidelines based on best practices. EDULEARN14 Proceedings, 6981-6990. Retrieved from http://eeyem.eap.gr/sites/default/files/EDULEARN14_paper\%20draft.pdf

Valverde, J. (2014). MOOCs: una visión crítica desde las Ciencias de la Educación. Profesorado Revista de currículum y formación del profesorado, 18(1), 93-111.

Vázquez, E., López, E., \& Sarasola, J. L. (2013). La expansión del conocimiento en abierto: los MOOC. Barcelona, España: Octaedro-ICE-UB.

Yousef, A. M. F., Chatti, M. A., Wosnitza, M., \& Schroeder, U. (2015). Análisis de clúster de perspectivas de participantes en MOOC. RUSC Universities and Knowledge Society Journal, 12(1), 74-91. http://dx.doi.org/10.7238/rusc.v12i1.2253

\section{Submit your manuscript to a SpringerOpen ${ }^{\circ}$ journal and benefit from:}

- Convenient online submission

- Rigorous peer review

- Immediate publication on acceptance

- Open access: articles freely available online

- High visibility within the field

- Retaining the copyright to your article

Submit your next manuscript at $\boldsymbol{~ s p r i n g e r o p e n . c o m ~}$ 